\title{
Czy w NRD istniala cenzura literacka? Przeksztalcenia i biurokratyczno-organizacyjne umocowanie urzędu kontroli literatury w NRD
}

Koniec II wojny światowej i bezwarunkowa kapitulacja Trzeciej Rzeszy przyniosły decydujące zmiany w polityce kulturalnej Niemiec, które według postanowień państw alianckich podzielono na cztery strefy okupacyjne: amerykańską, francuską, brytyjską i radziecką. Władze wojskowe państw alianckich prowadziły początkowo we wszystkich strefach okupacyjnych wspólną, ujednoliconą politykę denazyfikacji i demokratyzacji społeczeństwa niemieckiego. Cenzurą objęto wszystkie media i kanały komunikacji społecznej. Zakazano przede wszystkim rozpowszechniania treści militarno-wojskowych, rasistowskich, narodowosocjalistycznych oraz takich, które mogłyby w negatywnym świetle przedstawiać państwa alianckie okupujące tereny niemieckie. Licencji potrzebnych do produkcji i dystrybucji druków udzielano tylko osobom niepodejrzanym, które poddały się procesowi denazyfikacji oraz działały na rzecz demokracji i pokoju. Wspierano też instytucje i organizacje niemieckie, które propagowały sztukę zaangażowaną na rzecz demokratyzacji życia społecznego. W miarę upływu pierwszych dwóch lat wspólne drogi państw alianckich stopniowo się rozchodziły - podczas gdy w zachodnich strefach okupacyjnych polityka denazyfikacji stawała się coraz łagodniejsza, na terenach zajętych przez Związek Radziecki nacisk ideologiczny był coraz większy. Nasilające się konflikty między zachodnimi państwami alianckimi i trwająca od 1947 roku zimna wojna doprowadzily do powstania jesienią 1949 dwóch państw niemieckich: Republiki Federalnej Niemiec, współpracującej z państwami zachodnimi, i Niemieckiej Republiki Demokratycznej, pozostającej - tak jak inne państwa Europy Środkowo-Wschodniej - w strefie dominacji Związku Radzieckiego.

Postawione w tytule artykułu pytanie w pewien sposób oddaje stan rzeczy, jaki w odniesieniu do wolności słowa w NRD trwał od początku istnienia tego

* Dr hab., e-mail: mrajch@amu.edu.pl; Uniwersytet im. Adama Mickiewicza w Poznaniu, Wydział Neofilologii, Instytut Filologii Germańskiej, Zakład Polsko-Niemieckich Stosunków Literackich.

${ }^{1}$ Zob. D. Breuer, Geschichte der literarischen Zensur in Deutschland, Quelle \& Meyer, Heidelberg 1962, s. 239-240. 
państwa. Odpowiednie artykuły konstytucji NRD z 1949 roku i jej znowelizowanej wersji z roku 1968 gwarantowały wszystkim obywatelom tego państwa wolność wypowiedzi ${ }^{2}$. Główni decydenci enerdowscy przy różnych okazjach albo dawali wyraz zdziwieniu, jakoby w ich państwie miała funkcjonować cenzura, albo zdecydowanie zaprzeczali jej istnieniu ${ }^{3}$. Rzeczywistość była jednak zgoła inna aniżeli wrażenie, jakie chcieli wywołać autorzy tych opinii. Obywatele NRD cieszyli się dużo mniejszą swobodą wypowiedzi niż obywatele innych państw socjalistycznych. Jednocześnie nie istniała w tym kraju instytucja, która - podobnie jak Główny Urząd Kontroli Prasy, Publikacji i Widowisk w PRL - ze swojej nazwy zajmowała się (tylko i wyłącznie) kontrolą komunikacji literackiej i publicznej w ogóle. Pytanie o cenzurę literacką w NRD ma nie tyle podawać w wątpliwość niepodważalną kwestię jej istnienia, ile skierować uwagę na jej specyficzne umocowanie w organizacyjno-biurokratycznym systemie władzy komunistycznej.

Różnice między instytucjami mającymi w przyszłości zajmować się w obu krajach cenzurą były widoczne już w momencie ich tworzenia. Wspólny dla urzędów cenzury w PRL i NRD był fakt udziału w ich powoływaniu specjalnych wysłanników ze Związku Radzieckiego, sprawdzonych na tym polu działania komunistycznych władz. O ile jednak peerelowski GUKPPiW powstał w ciągu dwóch lat w wyniku kilku organizacyjnych przeobrażeń i jego ostateczna struktura została potwierdzona dekretem prezesa Rady Ministrów z 5 lipca 1946 roku $^{4}$, o tyle proces powstawania odpowiadającego mu urzędu w sąsiedniej NRD trwał znacznie dłużej i był bardziej złożony.

W pierwszych latach powojennych cenzura prasy, literatury, filmu i pozostałych mediów sprawowana była przez radziecką administrację wojskową, która niedwuznacznie dała ludziom sztuki do zrozumienia, że ich twórczość i aktywność artystyczna będą zależały wprost od ich stosunku do ZSRR ${ }^{5}$. Dekret, w którym po raz pierwszy jest mowa o urzędzie cenzury na wschodnich terenach Niemiec, został wydany przez radziecką administrację wojskową 2 sierpnia 1945 roku i opatrzony był numerem dziewiętnastym. Określał tymczasowe zasady udzielania zgody na druk, a także przyporządkowanie organizacyjne urzędu cenzury radzieckiej administracji wojskowej. Nadzór nad nim sprawował major Iwan Filipow, który podlegał bezpośrednio szefowi Wydziału Politycznego Władimirowi Semjonowi ${ }^{6}$.

\footnotetext{
2 Zob. D. Breuer, dz. cyt., s. 242.

${ }^{3}$ Zob. G. Herzberg, Anpassung und Aufbegehren. Die Intelligenz der DDR In den Krisenjahren 1956/58, Christoph Links Verlag, Berlin 2006, s. 275.

${ }^{4}$ Zob. Z. Romek, Cenzura a nauka historyczna w Polsce 1944-1970, Wydawnictwo Neriton, Warszawa 2010, s. 21-37.

${ }^{5}$ Zob. D. Breuer, dz. cyt., s. 241.

${ }^{6}$ Zob. P. Strunk, Zensur und Zensoren. Medienkontrolle und Propagandapolitik unter sowjetischer Besatzungsherrschaft in Deutschland, Akademie Verlag, Berlin 1996, s. 92-95.
} 
Ważnym etapem w rozwoju cenzury w NRD było utworzenie w 1946 roku Rady Kultury ds. Wydawnictw (Kultureller Beirat für das Verlagswesen) działającej przy radzieckiej administracji wojskowej. Do jej głównych zadań należało cenzurowanie wydawnictw prywatnych, które nie zostały jeszcze znacjonalizowane. Na podstawie przedłożonych przez wydawnictwa maszynopisów organ ten udzielał zezwoleń na druk i decydował o przyznaniu papieru. Rada Kultury ds. Wydawnictw była zalążkiem i bezpośrednim poprzednikiem właściwego urzędu cenzury, który miał powstać dopiero kilka lat później

W 1951 roku, niespełna dwa lata po utworzeniu NRD, powołano do życia Urząd Literatury i Wydawnictw (Amt für Literatur und Verlagswesen; ULiW). Zarówno nazwa nowo powstałej instytucji, jak i odpowiednie rozporządzenie powołujące ją do życia były sformułowane w taki sposób, aby odwrócić uwagę od właściwego zadania urzędu. Zgodnie z literą Rozporządzenia o rozwoju literatury postępowej (Verordnung über die Entwicklung fortschrittlicher Literatur) głównym zadaniem nowego urzędu miało być ,podniesienie jakości literatury w procedurze opiniowania planowanych utworów". Szczegółowe przepisy z 13 grudnia 1951 roku określające zakres działalności ULiW nie pozostawiały złudzeń co do tego, jakie miał podejmować zadania. Formalnie chodziło o zapewnienie odpowiednich warunków do produkcji i dystrybucji książek oraz prasy na terenie całego kraju. Do kompetencji tej instytucji należało przyznawanie licencji wydawniczych i coroczna kontrola planów wydawniczych poszczególnych instytucji. Wspomniane przepisy wykonawcze zobowiązywały także oficyny do przedłożenia każdego maszynopisu w Urzędzie Literatury i Wydawnictw. Jego pracownicy po uprzednim sprawdzeniu wydawali opinię i zwalniali je do druku bądź wstrzymywali dalsze procedowanie?.

Opiniowaniem przedłożonych maszynopisów i zwalnianiem ich do druku zajmował się - będący częścią ULiW - Wydział Opinii (Abteilung Begutachtung), który do 1963 roku odpowiadał także za kontrolowanie czasopism i w praktyce do tego czasu był centralnym urzędem cenzury na terenie NRD. W latach 1954 i 1955 Urząd Literatury i Wydawnictw otrzymał dodatkowe zadania: zatwierdzanie i ocena planów wydawniczych oraz intensywna (współ)praca z redakcjami ${ }^{10}$.

Utworzony w 1951 roku Urząd Literatury i Wydawnictw nie był ostateczną organizacyjną formą instytucjonalnej cenzury w NRD. Aparat cenzury w tym kraju tworzył bardzo złożoną sieć różnych instytucji, których kompetencje decyzyjne

\footnotetext{
${ }^{7}$ Zob. S. Lokatis, Vom Amt für Literatur und Verlagswesen zur Hauptverwaltung Verlagswesen im Ministerium für Kultur, [w:] S. Barck, M. Langermann, S. Lokatis, ,, Jedes Buch ein Abenteuer". Zensur-System und literarische Öffentlichkeit in der DDR bis Ende der sechziger Jahre, Akademie Verlag, Berlin 1998, s. 19-22.

${ }^{8}$ Zob. S. Lokatis, Vom Amt für Literatur..., s. 19.

${ }^{9}$ Zob. D. Breuer, dz. cyt., s. 243.

${ }^{10}$ Zob. S. Lokatis, Vom Amt für Literatur..., s. 19.
} 
często się pokrywały. Elementem w największym stopniu komplikującym tę trudną sytuację była forma własności poszczególnych wydawnictw. Obok istniejących jeszcze na początku lat pięćdziesiątych XX wieku prywatnych wydawnictw o tradycji przedwojennej funkcjonowały na terenie NRD wydawnictwa założone przez nowe władze po wojnie, które były albo wydawnictwami państwowymi, albo partyjnymi. ULiW zobowiązany był nadzorować z jednej strony aspekt ekonomiczny działalności wydawniczej, a z drugiej - jej zgodność z aktualnymi założeniami polityki kulturalnej. Właścicielami wielu wydawnictw były: Socjalistyczna Partia Jedności Niemiec (Sozialistiche Einheitspartei Deutschlands, SED), w której imieniu działało Zrzeszenie Wydawnictw i Drukarni (Druckerei- Und Verlagskontor) oraz Zjednoczenie Przedsiębiorstw Państwowych (Verwaltung Volkseigener Betriebe). Ponieważ instytucje te miały ambicje, aby wpływać na kierunek działalności podlegających im redakcji wydawniczych, konflikty między nimi a Urzędem Literatury i Wydawnictw były nieuniknione. Przezwyciężenie problemów stało się ważne, gdyż utrudniały one ona skuteczne kierowanie ruchem wydawniczym. Próbowano tego dokonać, podejmując w kolejnych latach - aż do 1963 roku - wiele organizacyjno-strukturalnych i administracyjnych przekształceń ULiW. Miały one doprowadzić do tego, aby jedna centralna instytucja sprawowała faktyczną kontrolę polityczno-kulturalną i ekonomiczną nad całym ruchem wydawniczym w kraju. Transformacjom instytucji zajmującej się cenzurą towarzyszyła każdorazowo zmiana jej nazwy.

Istotnym krokiem w kierunku udoskonalenia systemu cenzury w NRD było połączenie w 1955 roku dwóch odrębnych wydziałów działających w Urzędzie Literatury i Wydawnictw - Wydziału Planowania (Abteilung Planung) i Wydziału Opiniowania (Abteilung Begutachtung). Przy wprowadzaniu tej zmiany kierowano się zasadą, że efektywność ekonomiczna wydawnictw powinna iść w parze ze zgodnością z aktualnymi założeniami polityki kulturalnej. Kontrola działalności wydawniczej miała odtąd odbywać się nie dopiero po przedłożeniu w urzędzie gotowego maszynopisu do zaopiniowania, ale już na etapie włączania poszczególnych pozycji do planu wydawniczego ${ }^{11}$.

Pierwszą próbę przezwyciężenia sporów kompetencyjnych między instytucjami nadzorującymi działalność wydawniczą podjęto w 1956 roku. Polegała ona na tym, że ULiW podporządkowano bezpośrednio wydawnictwa branżowe, które do tej pory nadzorowane były przez Zjednoczenie Przedsiębiorstw Państwowych. W wyniku tych zmian zlikwidowano istniejący od 1951 roku Urząd Literatury i Wydawnictw, a w jego miejsce utworzono Naczelny Zarząd Wydawnictw (Hauptverwaltung Verlagswesen), który włączono jednocześnie w strukturę Ministerstwa Kultury ${ }^{12}$.

${ }^{11}$ Zob. tamże, s. 48-60.

${ }^{12}$ Zob. tamże, s. 39-40. 
Nie bez wpływu na politykę kulturalną, a także sposób sprawowania i instytucjonalne przeobrażenia cenzury w NRD w pierwszych latach jej istnienia, pozostały dramatyczne wydarzenia społeczno-polityczne zarówno w tym kraju w czerwcu 1953 roku, jak i w sąsiadującej z nim Polsce i na Węgrzech trzy lata później. W roku 1953 na krótko złagodzono kryteria cenzury, a z inicjatywy pracowników Wydziału Opiniowania zmieniono sposób pracy z redakcjami wydawnictw, kierując się dewizą ,przekonywać zamiast zarządzać” (überzeugen statt administrieren). W myśl tej zasady problematyczne teksty należało poddać kolektywnej dyskusji w zespołach redakcyjnych ${ }^{13}$.

Swego rodzaju odpowiedzią na wydarzenia w Polsce i na Węgrzech i - co ważniejsze - na pojawiające się $\mathrm{w}$ związku z tym w NRD postulaty zliberalizowania cenzury miała być zainicjowana przez kierownictwo partii na XXX Plenum w styczniu 1957 roku ,ideologiczna ofensywa” (nie tylko) w dziedzinie kultury. Członkowie Komitetu Centralnego partii musieli przyznać, że ich dotychczasowa polityka kulturalna nie była skuteczna. Zauważali w pierwszej kolejności brak literatury ze Związku Radzieckiego i innych krajów socjalistycznych. Wskazywali także na niedostateczny rozwój takiej literatury współczesnej, która spełniałaby wymagania polityki kulturalnej i proklamowanego kilka lat wcześniej realnego socjalizmu. Do problemów natury ideologiczno-politycznej doszła może jeszcze bardziej dotkliwa sytuacja ekonomiczna. Ze względu na słabnącą w ostatnich latach wymianę produkcji wydawniczej nie tylko z krajami socjalistycznymi, ale przede wszystkim kapitalistycznymi, istotnym problemem stał się brak dewiz. Z inicjatywy kierownictwa partii utworzono komisję, która miała przyjrzeć się metodom pracy i skuteczności instytucji odpowiadających za produkcję wydawniczą. Jednocześnie zwołano konferencję mającą na celu wypracowanie takich narzędzi, które przyczyniłyby się do podniesienia jakości krajowej produkcji wydawniczej ${ }^{14}$.

W wyniku podjętych działań zlikwidowano w 1958 roku istniejący zaledwie od dwóch lat Naczelny Zarząd Wydawnictw i w jego miejsce utworzono Wydział Literatury i Książki (Abteilung Literatur und Buchwesen). Tworząc nową instytucję, położono szczególny nacisk na ponowne wyodrębnienie Wydziału Opiniowania, co miało w znacznym stopniu polepszyć ideologiczną kontrolę maszynopisów zgłaszanych do druku, zaniedbaną w ostatnich dwóch latach ${ }^{15}$. Do najważniejszych zadań tego urzędu należał ideologiczny nadzór nad działalnością wydawnictw, konstruowanie planów wydawniczych i planów perspektywicznych oraz wspomniane opiniowanie przedłożonych do druku pozycji. Urząd był

${ }^{13}$ Zob. tamże, s. 39.

${ }^{14}$ S. Lokatis, Die ,,ideologische Offensive der SED”, die Krise des Literaturapparates 1957/158 und die Gründung der Abteilung Literatur und Buchwesen, [w:] S. Barck, M. Langermann, S. Lokatis, dz. cyt., s. 61-74.

${ }^{15}$ Por. tamże, s. $85-86$. 
podzielony na referaty, do których przypisane były poszczególne wydawnictwa branżowe. Referaty pod względem merytorycznym i ideologicznym podlegały właściwym ministerstwom branżowym, co w praktyce sprowadzało się do tego, że Wydział Literatury i Książki pełnił raczej funkcję koordynującą niż kierowniczą w stosunku do wydawnictw. Tym samym nowo utworzona instytucja cenzury straciła (przynajmniej na kilka lat) wpływy w wydawnictwach technicznych i naukowych, ale zwiększyła je w stosunku do oficyn specjalizujących się w literaturze pięknej ${ }^{16}$.

Większe możliwości kierowania polityką wydawniczą w zakresie literatury pięknej przejawiały się m.in. w tym, że utworzony w ramach Wydziału Literatury i Książki Dział Literatury Pięknej (Belletristik-Abteilung) podzielono na referaty odpowiedzialne kolejno za: literaturę NRD, literaturę klasyczną, literaturę zagraniczną oraz literaturę dziecięcą i młodzieżową. Kierownik każdego referatu odpowiadał za współpracę z autorami i wydawnictwami, konstruowanie planów wydawniczych, przydział papieru oraz ustalanie wysokości nakładu. Za wydawanie opinii wydawniczych i zezwoleń na druk odpowiadał inny pracownik tego samego referatu ${ }^{17}$.

Usprawnieniu cenzury w NRD zdecydowanie sprzyjał kryzys gospodarczy końca lat pięćdziesiątych, który przejawiał się brakiem papieru i innych materiałów potrzebnych w produkcji wydawniczej. Wydawnictwa, zależne w tym względzie od Wydziału Literatury i Książki, starały się zjednać sobie przychylność jego pracowników oraz uznanie dla swojej produkcji wydawniczej, a równocześnie wychodzić naprzeciw stawianym oczekiwaniom. Prowadziło to do tego, że chcąc zabezpieczyć własne interesy, redakcje wydawnictw nie tylko ze sobą konkurowały, lecz także w coraz większym stopniu realizowały politykę literacką państwa. Badacze cenzury w NRD oceniają, że aktywne włączenie wydawnictw w system cenzury, które nastąpiło pod koniec lat pięćdziesiątych, było jednym z najważniejszych momentów w rozwoju kraju ${ }^{18}$.

Nie zmienia to jednak faktu, że wszystkie dotychczasowe zmiany w ramach instytucji odpowiedzialnej za kierowaniem ruchem wydawniczym nie doprowadziły jeszcze do powstania w pełni wydajnego systemu kontroli. Największym problemem były relacje pracowników Wydziału Literatury i Książki z instytucją, która nadzorowała wydawnictwa będące własnością partii. Efektywną współpracę zakłócało wiele nierozstrzygniętych, kłopotliwych i spornych kwestii natury organizacyjno-kompetencyjnej: jednolite planowanie pracy wydawnictw, całoroczna kontrola realizacji planu wydawniczego, dalsze kierowanie i specjalizacja wydawnictwa. Największych problemem było kwestionowanie przez Druckerei-

\footnotetext{
${ }^{16}$ Por. tamże, s. 91.

${ }^{17}$ Zob. tamże, s. 93-96.

${ }^{18}$ Zob. tamże.
} 
und Verlagskontor prawa Wydziału Literatury i Książki do ideologiczno-politycznego nadzoru nad działalnością wydawnictw partyjnych ${ }^{19}$.

Sytuacja uległa zmianie na początku lat sześćdziesiątych. Stojący na czele Wydziału Literatury i Książki Erich Wendt podjął w maju 1961 roku próbę włączenia wydawnictw i księgarń partyjnych w struktury Ministerstwa Kultury. Nieświadomie przyszedł mu z pomocą pierwszy sekretarz Socjalistycznej Partii Jedności Niemiec Walter Ulbricht, który w tym samym czasie upominał się o podjęcie przez aparat rządowy działań zmierzających do przezwyciężenia „rozproszenia pracy kulturalnej wśród mas" oraz kryzysu w produkcji wydawniczej i handlu książkami. Pod koniec lipca 1962 roku Biuro Polityczne przyjęło odpowiednią uchwałę, której celem była poprawa sytuacji na rynku książki i skuteczna organizacja nadzoru ruchu wydawniczego. W konsekwencji tej uchwały Rada Ministrów wydała rozporządzenie o utworzeniu w ramach Ministerstwa Kultury Naczelnego Zarządu Wydawnictw i Księgarstwa (Hauptverwaltung Verlage und Buchhandel; NZWiHS). Swoją działalność instytucja miała rozpocząć 1 stycznia 1963 roku, a odpowiednie przepisy wykonawcze, regulujące jej funkcjonowanie zostały wydane przez ministra kultury 7 stycznia i 7 marca tego roku ${ }^{20}$.

Podstawową zasadą, jaką miał się kierować Naczelny Zarząd Wydawnictw i Księgarstwa, była ,jedność polityki kulturalnej i ekonomii” ${ }^{21}$. Personalnie wydawcy mieli w swojej pracy wykazywać się cechami ideologa i ekonomisty. Tym samym stawali się odpowiedzialni nie tylko za ustalanie wysokości nakładów poszczególnych tytułów, ale również za ewentualne trudności z ich sprzedażą. Pracownicy NZWiHS określali tylko maksymalną wysokość nakładu, której nie można było przekroczyć. Wydawcy natomiast, składając wniosek o wydanie zezwolenia na druk, musieli w przekonujący sposób wykazać, że ukazanie się planowej pozycji we wnioskowanej przez nich liczbie egzemplarzy jest zasadne, tzn. znajdzie odpowiednią liczbę nabywców i nie będzie zalegać w magazynach ${ }^{22}$.

Utworzenie w 1963 roku Naczelnego Zarządu Wydawnictw i Księgarstwa było ostatnim etapem w procesie centralizacji i profesjonalizacji cenzury w NRD. O centralizacji można mówić w tym sensie, że o ile na początku istnienia kraju nadzór ekonomiczny i polityczno-ideologiczny nad działalnością wydawnictw był podzielony między różne konkurujące ze sobą instytucje, o tyle w 1963 roku powstał urząd, który łączył w sobie obie te funkcje. Wskutek wielokrotnych przekształceń strukturalno-organizacyjnych urzędu zajmującego się kontrolą produkcji wydawniczej udało się w znacznym stopniu uszczelnić system cenzury i zwiększyć jego skuteczność, kierując się zasadą, że wydawcy

\footnotetext{
${ }^{19}$ Por. S. Lokatis, Die Hauptverwaltung Verlage und Buchhandel, [w:] S. Barck, M. Langermann, S. Lokatis, dz. cyt., s. 175.

${ }^{20}$ Zob. tamże, s. $176-180$.

${ }^{21}$ Por. tamże, s. 186.

${ }^{22}$ Zob. tamże.
} 
książek powinni przejąć odpowiedzialność za swoje publikacje. Wydawnictwa miały stać się „polityczno-ideologicznymi ośrodkami”"23, które wobec autorów reprezentowały politykę kulturalną partii i państwa.

Pracownicy wydawnictw bardzo szybko przystosowali się do stawianych im warunków. Propozycje płynące ze strony pracowników NZWiHS wydawcy rozumieli często jako dyrektywy, które należało bezwzględnie wypełnić. Miało to negatywne skutki dla samych autorów, ponieważ procedury dopuszczenia poszczególnych pozycji do druku trwały bardzo długo i były często mało przejrzyste ${ }^{24}$.

Utworzony w 1963 roku Naczelny Zarząd Wydawnictw i Księgarstwa istniał do momentu zjednoczenia Niemiec w 1990 roku. Spełniał on - jeśli nie w pełni, to z pewnością w daleko idącym stopniu - warunki idealnej instytucji cenzury. Mimo iż cenzurowanie przedłożonych do druku pozycji należało do jednego z głównych zadań zatrudnionych w nim pracowników, nie miało to odzwierciedlania w nazwie urzędu. Poza tym funkcja kontroli została niejako dodatkowo ukryta w konglomeracie wszystkich innych zadań urzędu, których celem nadrzędnym było kierowanie ruchem wydawniczym. W konstruowaniu tak niemalże perfekcyjnie działającego systemu cenzury NRD nie była do końca oryginalna. Wiele wskazuje na to, że postulaty stworzenia doskonałego systemu kontroli publikacji były wspólne dla całego bloku państw socjalistycznych. Wydaje się jednak, że właśnie Niemiecka Republika Demokratyczna osiągnęła w ich realizacji najlepsze rezultaty.

\section{Bibliografia}

Breuer D., Geschichte der literarischen Zensur in Deutschland, Quelle \& Meyer, Heidelberg 1962. Herzberg G., Anpassung und Aufbegehren. Die Intelligenz der DDR In den Krisenjahren 1956/58, Christoph Links Verlag, Berlin 2006.

Lokatis S., Die Hauptverwaltung Verlage und Buchhandel, [w:] S. Barck, M. Langermann, S. Lokatis: ,Jedes Buch ein Abenteuer”. Zensur-System und literarische Öffentlichkeit in der DDR bis Ende der sechziger Jahre, Akademie Verlag, Berlin 1998, s. 173-226.

Lokatis S., „Die ideologische Offensive der SED”, die Krise des Literaturapparates 1957/158 und die Gründung der Abteilung Literatur und Buchwesen, [w:] S. Barck, M. Langermann, S. Lokatis: „Jedes Buch ein Abenteuer”. Zensur-System und literarische Öffentlichkeit in der DDR bis Ende der sechziger Jahre, Akademie Verlag, Berlin 1998, s. 61-96.

Lokatis S, Vom Amt für Literatur und Verlagswesen zur Hauptverwaltung Verlagswesen im Ministerium für Kultur, [w:] S. Barck, M. Langermann, S. Lokatis: „Jedes Buch ein Abenteuer”. Zensur-System und literarische Öffentlichkeit in der DDR bis Ende der sechziger Jahre, Akademie Verlag, Berlin 1998, s. 19-60.

Romek Z., Cenzura a nauka historyczna w Polsce 1944-1970, Wydawnictwo Neriton, Warszawa 2010. Strunk P., Zensur und Zensoren. Medienkontrolle und Propagandapolitik unter sowjetischer Besatzungsherrschaft in Deutschland, Akademie Verlag, Berlin 1996.

${ }^{23}$ Por. tamże, s. 197.

${ }^{24}$ Zob. tamże, s. 188, 197-199. 


\author{
Marek Rajch
}

Did literary censorship exist in the GDR? Transformations and bureaucratic-organisational position of the office for the controll of literature in the GDR

\title{
(Summary)
}

In communist countries censorship offices were the final link in the entire process of control of a given literary text before its publication. The Polish Central Office for the Control of Press, Publications and Performances of the ideological and political control of the manuscripts submitted. The [formulation of the] publication schedule and monitoring its implementation was done by institutions answerable to the Ministry of Culture and Art. In the GDR right from the start attempts were made to concentrate the two forms of control in one institution, which ultimately took place in 1963 after the establishment of the Central Board of Publishing Houses and Book Trade (Hauptverwaltung Verlage und Buchhandel). This institution held logistical and economic control of publishing houses, supervising from day one the publication schedules and monitoring the books prepared for issue as to their ideological and political content. It also made the final decision as to whether given books can come out and on what conditions, or whether their publication should be prevented.

Keywords: literary censorship; publishing production; GDR; ideological and economic control of publishing houses. 